Peshawar Journal of Psychology and Behavioral Sciences, 2016, Vol. 2, No. 1, 47-57

\title{
Changing Attitude Towards Women Education: An Outcome of Benefits of Women Education in Rural Area
}

\author{
Hamyon ${ }^{1}$, Mushtaq Ahmad Jadoon ${ }^{2}$, \\ Alamgeer Khan ${ }^{3}$, Intikhab Alam ${ }^{4}$, Muhammad \\ Jawad $^{5}$ Saima Sarir ${ }^{6} \&$ Anwar Shah ${ }^{7}$ \\ The University of Agriculture Peshawar, Pakistan
}

Female constitute half of country population but still facing problem in almost all sectors of life in the male dominating Pakistani society. The major aim of the present study was to find out the benefits of female education as factor affecting their parent's attitude towards education. Data for the study were collected from two hundred and fourteen $(\mathrm{N}=214)$ respondents belonging to two selected villages of district Bannu. A significant association was found among attitude about female education and by getting education females would become good housewives, good mothers, would be able to get better life partners, would bring up their children in a better way and could help their children in educational and social problems. Furthermore they would have job opportunities, would be socioeconomically empowered, would make sensible decisions in important matters and they would be less likely to marry early. On the basis of encouraging findings of the study about expected benefits of female educations it is recommended that

\footnotetext{
M.Phil Scholar, Department of Rural Sociology, The University of Agriculture, Peshawar

2 Assistant Professor, Department of Rural Sociology, The University of Agriculture, Peshawar

${ }^{3}$ Lecturer, Department of Rural Sociology (AMK Campus Mardan), University of Agriculture, Peshawar Alamgeer@aup.edu.pk

${ }^{4}$ Lecturer, Department of Rural Sociology, The University of Agriculture, Peshawar ${ }^{5}$ Lecturer, Department of Rural Sociology, The University of Agriculture, Peshawar ' Lecturer, Department of Rural Sociology, The University of Agriculture, Peshawar ${ }^{\succ}$ Lecturer, Department of Sociology, Bacha Khan University, Charsadda
} 
government and non-government organizations should keep people aware by highlighting these benefits which will ultimately motivate parents to provide education to their female children.

Keywords. Female, benefits, parents and attitude

Education is a fundamental right of each individual. Providing educational facilities to all its individuals is the obligation of society. From social perspective, education is directly connected to the development of the society. Females comprise half of Pakistan's population. If we do not educate this youth portion of our population, our country cannot make progress on sound basis (Rafi et al., 2012). No society has ever freed itself socially, economically or politically without a sound basis of educated women. In this case, education can play a vital role in boosting women's status and putting them on the same footing as their male counterparts and it also enhances women's ability to get jobs in the formal sector (Noureen and Awan, 2011).

Female education has been recognized as more critical for the development of nations than just education as a whole. It is now broadly acknowledged that the social benefits to female education are greatly increasing than male education because development cannot take place without women's participation in society. Education empowers women to take part in the implementation of necessary social changes, for example raising smaller and healthier families; while uneducated women generally bear more children. Educated girls are having more capability to make their own decisions rather than depending only on their parents or families, which allow them to be more self-contained. This shows that education is a crucial factor in the advancement of any society.

A country can't achieve development without the involvement of women in society and government. Women's participation in government is not only an essential solution, but government's decisions can also be positively affected by their participation (Mareng, 2010). If educated girls become mothers, it's much more probable that they would send their children to school, thus they transmit and increase benefits both for themselves and society in a form of positive intergenerational 
effect (Mishra, 2005). All over the world, education is considered as the key factor to surmount the obstacles that women face in life.

Education familiarizes women with issues of home management (Goel, 2004). Furthermore Education is considered as a critical factor in getting over the hurdles, that women face and an essential instrument for empowering women and involving them into the mainstream of development. Education not only provides awareness and skills to improve health and means of earning, but it also empowers women to get their right position in the society and development process. Education also gives status and confidence in making decisions. Women education is the key to reduce poverty (Bukhsh, 2007). The literacy rate of Pakistan among the Asian countries is ranked 10th, while Pakistan is ranked $6^{\text {th }}$ among the SAARC countries. All these facts cause disappointment. The number of illiterate persons in Pakistan in 1951, was about 20 million while according to the census of 1998, 48 million people were illiterate in Pakistan and now in 2010-11 this number is 75.6 million (Mustafa, 2012).

\section{Sample}

Method

The study was based on primary data, conducted in 2014. All the parents or household heads residing in the two selected villages (Azim Kala and Abdullah Jan Kala) District Bannu and had at least one female child at school going age were the potential respondents of the study. A sample size of 214 out of the total 850 households (1998 Census Report of District Bannu) was randomly picked as per criteria devised by Sekaran (2003).

\section{Tool}

Tool comprising of items related to the research problem were constructed after pilot study and review by the expert in the field.

\section{Procedure}


Formal data collection was initiated with formal permission and brief introduction of the aims of the study to the participants. Data was collected through interview method individually. Participants were requested for their honest responses and were assured about the confidentiality of their opinions. All the participants cooperated and completed the survey questionnaires. At the end of every interview all the participants were thanked for their participation in the study.

\section{Conceptual Framework}

The following were the dependent and independent variables of the study.

Table 1

Conceptual Framework

\begin{tabular}{|c|c|}
\hline Independent Variables & Dependent Variables \\
\hline Female Education's Benefits & Attitude about Female Education \\
\hline
\end{tabular}

After the collection of data, it were first coded and then entered in computer by using SPSS software for analysis. The analysis of the data was made at uni and bivariate levels. The univariate analysis comprised of frequency distribution and percentages of the sampled respondents. Bivariate analysis was carried out to measure the association between dependent and independents variables. Chi-square and Fisher Exact tests were used to measure the association. The Chisquared test statistics for the test of independence summarizes how close the expected frequencies fall to the observed frequencies. It is represented by the symbol $x^{2}$. Karl Pearson introduced the statistics in 1900 and used in sociological studies to test the degree of independence (Tai, 1978). The formula used to compute Chi-square is given in the following:

$$
\chi^{2}=\sum_{i=1}^{r} \sum_{j=1}^{\mathrm{c}} \frac{\left(O_{i j}-E_{i j}\right)^{2}}{E_{i j}}
$$


Where $x^{2}$ is chi-square, oij is observed frequencies in $\mathrm{i}^{\text {th }}$ row and $\mathrm{j}^{\text {th }}$ column. Eij is expected frequencies in $\mathrm{i}^{\text {th }}$ row and $\mathrm{j}^{\text {th }}$ column whereas $\mathrm{r}$ is number or rows and $n$ is number of column. The large summation sign, $\Sigma$ (capital sigma), tells us to compute the fractions for each cell and then sum over all cells to get ${ }^{x^{2}}$.

Fisher exact test was used when the frequencies in the table was less than 5. Following was the formula of the test.

Fisher Exact Test

$$
=\frac{(a+b) !(c+d) !(a+c) !(b+d) !}{N ! a ! b ! c ! d !}
$$

Where $a, b, c$ and $d$ were the observed numbers in contingency table while " $n$ " were the total number of observations.

\section{Results}

This section first describes the univariate and bivariate results. At univariate level it states the results regarding dependent variable i-e attitude towards female education and independent variable i-e Female Education's Benefits. It is followed by the association between the two variables.

Table 2

Parents' Attitude towards Female Education

\begin{tabular}{|c|c|c|c|}
\hline Statements & Yes & No & $\begin{array}{l}\text { Do not } \\
\text { know }\end{array}$ \\
\hline Female education is necessary & $188(87.9)$ & $21(9.8)$ & $5(2.3)$ \\
\hline $\begin{array}{l}\text { Female education is need of the } \\
\text { day }\end{array}$ & $181(84.6)$ & $28(13.1)$ & $5(2.3)$ \\
\hline $\begin{array}{l}\text { There is no need of female } \\
\text { education }\end{array}$ & $14(6.5)$ & 195(91.1) & $5(2.3)$ \\
\hline $\begin{array}{l}\text { Educated females are more } \\
\text { successful }\end{array}$ & $173(80.8)$ & $33(15.4)$ & $8(3.7)$ \\
\hline $\begin{array}{l}\text { Educated females are better } \\
\text { mothers }\end{array}$ & $177(82.7)$ & $32(15.0)$ & $5(2.3)$ \\
\hline
\end{tabular}




\begin{tabular}{|c|c|c|c|}
\hline $\begin{array}{l}\text { Female education is a wastage } \\
\text { of time and money }\end{array}$ & $15(7.0)$ & 191(89.3) & $8(3.7)$ \\
\hline Females should stay at home & $52(24.3)$ & $157(73.4)$ & $5(2.3)$ \\
\hline $\begin{array}{l}\text { Females should be given } \\
\text { limited schooling }\end{array}$ & $60(28.0)$ & $148(69.2)$ & $6(2.8)$ \\
\hline $\begin{array}{l}\text { Females should be given } \\
\text { higher education }\end{array}$ & $148(69.2)$ & $61(28.5)$ & $5(2.3)$ \\
\hline $\begin{array}{l}\text { Females should admit in better } \\
\text { schools }\end{array}$ & $168(78.5)$ & $41(19.2)$ & $5(2.3)$ \\
\hline $\begin{array}{l}\text { Females should admit in less } \\
\text { better schools }\end{array}$ & $33(15.4)$ & $168(78.5)$ & $13(6.1)$ \\
\hline
\end{tabular}

Table 3

Expected Benefits of Female Education

\begin{tabular}{|c|c|c|c|}
\hline Statements & Yes & No & Do not know \\
\hline $\begin{array}{l}\begin{array}{l}\text { Females will become good } \\
\text { housewives }\end{array} \\
\end{array}$ & 186(86.9) & $23(10.7)$ & $5(2.3)$ \\
\hline $\begin{array}{l}\text { Females will become good } \\
\text { mothers }\end{array}$ & $183(85.5)$ & $26(12.1)$ & $5(2.3)$ \\
\hline $\begin{array}{l}\text { Females will be able to get better } \\
\text { life partners }\end{array}$ & $177(82.7)$ & $30(14.0)$ & $7(3.3)$ \\
\hline $\begin{array}{l}\text { Educated females can bring up } \\
\text { their children in a better way }\end{array}$ & $172(80.4)$ & $37(17.3)$ & $5(2.3)$ \\
\hline $\begin{array}{l}\text { Educated females can help their } \\
\text { children in educational problems }\end{array}$ & 192(89.7) & $17(7.9)$ & $5(2.3)$ \\
\hline $\begin{array}{l}\text { Educated females can help their } \\
\text { children in social problems }\end{array}$ & $186(86.9)$ & $23(10.7)$ & $5(2.3)$ \\
\hline $\begin{array}{l}\text { Educated females have job } \\
\text { opportunities }\end{array}$ & $200(93.5)$ & $6(2.8)$ & $8(3.7)$ \\
\hline $\begin{array}{l}\text { Educated females are socio- } \\
\text { economically empowered }\end{array}$ & $174(81.3)$ & $32(15.0)$ & $8(3.7)$ \\
\hline Educated females make sensible & $177(82.7)$ & $32(15.0)$ & $5(2.3)$ \\
\hline
\end{tabular}


decisions in important matters

Educated females are less likely $152(71.0) \quad 52(24.3) \quad 10(4.7)$ to marry early

Source: Survey ${ }^{*}$ Frequencies are represented by figures in the table while percentages of the respondents are presented in parenthesis.

Table 4

Expected Benefits of Female Education and Attitude about Female Education

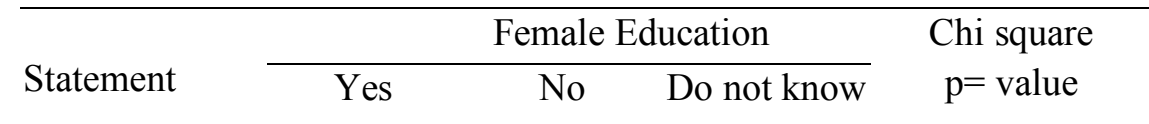

Females will become good housewives

$\begin{array}{ccccc}\text { Yes } & 162(97.0) & 23(76.7) & 1(5.9) & x^{2}=148.879 \\ \text { No } & 0(0.0) & 7(23.3) & 16(94.1) & (\mathrm{p}=.001) \\ \text { not know } & 5(3.0) & 0(0.0) & 0(0.0) & \end{array}$

Females will become good mothers

$\begin{array}{ccccc}\text { Yes } & 163(97.6) & 20(66.7) & 0(0.0) & x^{2}=155.312 \\ \text { No } & 0(0.0) & 9(30.0) & 17(100.0) & \\ \text { Do not know } & 4(2.4) & 1(3.3) & 0(0.0) & (\mathrm{p}=.001)\end{array}$

Females will be able to get better life partners

$\begin{array}{lcccc}\text { Yes } & 161(96.4) & 16(53.3) & 0(0.0) & x^{2}=146.288 \\ \text { No } & 2(1.2) & 11(36.7) & 17(00.0) & (\mathrm{p}=.001) \\ \text { not know } & 4(2.4) & 3(10.0) & 0(0.0) & \end{array}$

Do not know 4(2.4) 3(10.0) $\quad 0(0.0)$

Educated females can bring up their children in a better way

$\begin{array}{ccccc}\text { Yes } & 158(94.6) & 14(46.7) & 0(0.0) & x^{2}=125.488 \\ \text { No } & 6(3.6) & 14(46.7) & 17(00.0) & (p=.001) \\ \text { not know } & 3(1.8) & 2(6.7) & 0(0.0) & \end{array}$

Educated females can help their children in educational problems

$\begin{array}{ccccc}\text { Yes } & 165(98.8) & 20(66.7) & 7(41.2) & x^{2}=94.252 \\ \text { No } & 0(0.0) & 7(23.3) & 10(58.8) & (\mathrm{p}=.001) \\ \text { not know } & 2(1.2) & 3(10.0) & 0(0.0) & \end{array}$

Educated females can help their children in social problems 


\begin{tabular}{ccccc}
\hline Yes & $166(99.4)$ & $20(66.7)$ & $0(0.0)$ & $x^{2}=150.215$ \\
No & $0(0.0)$ & $8(26.7)$ & $15(88.2)$ & $(\mathrm{p}=.001)$ \\
Do not know & $1(0.6)$ & $2(6.7)$ & $2(11.8)$ & \\
Educated females have job opportunities \\
Yes & $161(96.4)$ & $25(83.3)$ & $14(82.4)$ & $x^{2}=30.590$ \\
No & $0(0.0)$ & $5(16.7)$ & $1(5.9)$ & $(\mathrm{p}=.001)$
\end{tabular}

$\begin{array}{lll}\text { Do not know } \quad 6(3.6) & 0(0.0) \quad 2(11.8)\end{array}$

Educated females are socio-economically empowered

$\begin{array}{lcccc}\text { Yes } & 155(92.8) & 19(63.3) & 0(0.0) & x^{2}=129.286 \\ \text { No } & 4(2.4) & 11(36.7) & 17(100.0) & (\mathrm{p}=.001)\end{array}$

Do not know $\quad 8(4.8) \quad 0(0.0) \quad 0(0.0)$

Educated females make sensible decisions in important matters

$\begin{array}{ccccc}\text { Yes } & 162(97.0) & 15(50.0) & 0(0.0) & x^{2}=136.273 \\ \text { No } & 2(1.2) & 15(50.0) & 15(88.2) & (\mathrm{p}=.001) \\ \text { not know } & 3(1.8) & 0(0.0) & 2(11.8) & \end{array}$

Educated females are less likely to marry early

\begin{tabular}{ccccc} 
Yes & $134(80.2)$ & $12(40.0)$ & $6(35.3)$ & $x^{2}=34.001$ \\
No & $29(17.4)$ & $15(50.0)$ & $8(47.1)$ & $(\mathrm{p}=.001)$ \\
Do not know & $4(2.4)$ & $3(10.0)$ & $3(17.6)$ & \\
\hline
\end{tabular}

Source: Survey * Frequencies are represented by figures in the table while percentages of the respondents are presented in parenthesis and in the end column number in parenthesis represents $p$ value.

\section{Discussion}

An attitude is a learned predisposition to respond in a favorable or unfavorable manner to a particular object, group, phenomenon, event or symbol. Attitudes are the basic determinants of human behavior. If a person perceives something favorable then his/her action must be favorable. Parents' attitude is very important for children education especially the female ones. If parents' attitude is positive their children 
will have higher education, otherwise they will have lower or no education.

Table 2 describes parents' perceptions about female education. The table states that $88,85,83,81,78$ and 69 percent of the sampled respondents expressed favorable attitude regarding the statements; female education is necessary, female education is need of the day, educated females are better mothers, educated females are more successful, females should admit in better schools and females should be given higher education respectively. A 91, 89, 78, 73 and 69 percent of the sampled respondents showed unfavorable attitude regarding the statements; there is no need of female education, female education is a wastage of time and money, females should admit in less better schools, females should stay at home and females should be given limited schooling respectively. Whereas a very few respondents expressed neither favorable nor unfavorable attitude in response to the above mentioned statements.

It's a human nature that he starts every activity for material/ non material gains. Female education is considered a useless investment in many backward societies. But nowadays people are becoming aware of the fact that it's a gainful investment for the future of new generation.

Table 3 while expressing views about expected benefits of female education states that 93 percent of the sampled respondents replied that educated females would have job opportunities as compared to uneducated or low educated females. Similarly 90, 87 each, 85, 83 each, 81,80 and 71 percent of the sampled respondents were also found confirming that educated females could help their children in educational problems, females would become good housewives, educated females could help their children in social problems, females would become good mothers, females would be able to get better life partners, educated females made sensible decisions in important matters, educated females would be socio-economically empowered, educated females could bring up their children in a better way and educated females would be less likely to marry early respectively. While minority of the respondents opposed and showed unawareness of the expected benefits of female education.

Overall results show that majority of the sampled respondents agreed upon the expected benefits of female education and they thought 
it a gainful activity. It means that female education will have a better future as people are realizing the role and value of female education.

About female education Napoleon once said, "give me an educated woman, I'll give you a strong nation”. Educated females are a blessing not only for their families but for the whole nation. No country can achieve its development goals without the contribution and share of women, which is possible only through educating this half portion of the population.

According to the table 4 a significant association was found between attitude about female education and females would become good housewives $(p=.000)$. Similarly attitude about female education and females would become good mothers $(\mathrm{p}=.000)$, females would be able to get better life partners $(\mathrm{p}=.000)$, educated females could bring up their children in a better way $(p=.000)$, educated females could help their children in educational problems $(\mathrm{p}=.000)$, educated females could help their children in social problems $(p=.000)$, educated females would have job opportunities $(p=.000)$, educated females would be socioeconomically empowered $(\mathrm{p}=.000)$, educated females would make sensible decisions in important matters $(\mathrm{p}=.000)$ and educated females would be less likely to marry early $(p=.000)$ were also associated significantly.

Results as a whole show a significant association of attitude about female education and expected benefits of female education. It indicates that due to material/non material gains from female education, parents were inclined to their daughters' education.

\section{Conclusion and Recommendations}

Showing linkage between attitude about female education and its expected benefits, a significant association was observed among attitude about female education and educated females would become good housewives and good mothers, they would be able to get better life partners, educated females could bring up their children in a better way, they could help their children in educational, could provide the solution of social problems of children, educated females would have job opportunities, they would be socio-economically empowered, educated 
females would make sensible decisions in important matters and they would be less likely to marry early.

On the basis of findings the study recommends that government should focus to maintain peace and harmony in the study area. This is because after $9 / 11$ the miscreants have destroyed many female schools in FATA and in the surrounding of Peshawar city. Consistent support to education institution and provision of female jobs opportunities are also recommended to keep the attitude of parents positive towards female education.

\section{References}

Bukhsh, Q. 2007. Empowerment of women through distance education in Pakistan. Turkish Online Journal of Distance Education. 8(4):135-151.

Goel, A. 2004. Education and socio-economic perspectives of women development and empowerment. Deep \& Deep Publications Pvt. Ltd., New Delhi.

Govt. of Pakistan. 1998. District census report of Bannu. Population Census Organization, Statistics Division, Islamabad, Pakistan.

Mareng, C. 2010. Development of Women's Education in Kenya. International NGO Journal. 5(3):68-73.

Mishra, R.C. 2005. Women education. A.P.H Publishing Corporation, New Delhi.

Noureen, G. and R.N. Awan. 2011. Women's education in Pakistan: Hidden fences on open frontiers. Asian Social Science. 7(2):7987.

Rafi, S., M. Ali and M.A. Aslam. 2012. What male thinks about female education? Case study of Sargodha district. International Journal of Economics and Research. 3(1):101-104.

Sekaran, U. 2003. Research methods for business. A skill building approach. 4th edition, John Willey and Sons, USA. 295p. 